\title{
Language policy-making in Ireland: A preliminary study of the consultation process of Languages Connect
}

\author{
Iker Erdocia, Susanna Nocchi, Mary Ruane \\ Dublin City University, Technological University Dublin, University College Cork \\ Iker.erdocia@dcu.ie,susanna.nocchi@tudublin.ie,.mruane12@gmail.com
}

\begin{abstract}
This study aims to explore the policy-making process of Languages Connect Ireland's Strategy for Foreign Languages in Education 2017-2026. For that purpose, we concentrate on the consultation process adopted by the Department of Education and Skills. Drawing on a concept of foreign language competence as human capital, the aim of this study is twofold. Firstly, we investigate the extent to which the submissions to the consultation process form a sequence with the final document, Languages Connect; secondly, we examine the Irish government documents and compare the submissions reflecting the government approach to language with those problematising such discourse. The former analysis reveals how a market-led valuing of languages is embedded in the government discourse. The latter analysis further shows that linguistic diversity did not receive as much attention as language competence. Bearing in mind that participatory and deliberative procedures are meant to provide legitimacy for policy decisions, the paper concludes by discussing some of the positionings taken in Languages Connect and the role of the procedural mechanisms employed in the consultation.
\end{abstract}

Keywords: Language policy and planning; policy analysis; participatory policy-making; deliberation; mixed methods research

\section{Introduction}

While globalisation, mobility, and social inclusion have led to the most fruitful period for language policy-making in history, the study of the processes of formulation of language policies ${ }^{1}$ has been widely neglected by applied linguists (Lo Bianco, 2013). This is because language policy-making is often depicted as a simply administrative or bureaucratic set of procedures and not as being fully embedded in interactive processes of discourse and in a terrain of power relations. Language management requires managerial decision-making based 
on different kinds of knowledge. These include the determination of the value of language and the realisation of particular visions of language provided by a wide range of voices and discourses (Ramberg, 2016). Following this approach, not only expert knowledge should have an authoritative voice in shaping language policy but public engagement in deliberative practices may be a major source of public justification.

With this in mind, this study is part of a wider research project that aims to explore the first stages - agenda-setting, policy formulation, and decision-making — of the policy-making process of Languages Connect - Ireland's Strategy for Foreign Languages in Education 20172026 (henceforth Languages Connect). Our aim is to contribute to the ongoing conversation (Maguire, 2019; Bruen, 2019) since Languages Connect was published, in 2017.

The strategy is the result of an extensive consultation launched in 2014 by the Department of Education and Skills (henceforth DES). In line with participatory governance mechanisms that are open to multiple sources of public influence, an important number of language-related professionals, private stakeholders and state bodies and agencies took part in the public consultation. In the present study, we concentrate on examining this consultation process.

Drawing on a concept of foreign language (FL) competence as human capital, we aim to investigate, first, the extent to which the submissions to the consultation process are reflected in the final document, Languages Connect. Secondly, we examine the Framework for Consultation on a Foreign Languages in Education Strategy for Ireland and Languages Connect and compare the submissions that reflect the Government approach to language with those submissions that problematise such discourse.

Our investigation starts with a presentation of the economic, political, and educational context in which the Government's initiative was launched, along with the proposed consultation framework itself. Given the participatory approach taken by public authorities, we situate our study within the framework of deliberative theories. We then outline the methodology adopted in choosing and coding the corpora and present our quantitative and qualitative findings. Lastly, we consider how our study sheds light on the discursive mechanisms involved in the consultation process and in the policy formation, as well as on the role of the procedural mechanisms employed in the consultation. 


\section{Economic, political, and educational context for Languages Connect}

Language education policy and planning (henceforth LPP) has a long and important research record in Irish public policy (Royal Irish Academy, 2011; Bruen, 2013). In the 2008-10 period, a particular set of national circumstances coalesced leading to very deliberate and planned government intervention in language education policy-making in one specific area, the teaching of foreign languages.

The new context was triggered by the Irish financial crash of 2008, "one of the biggest banking crises and deepest economic slumps of any country during the global financial crisis" (OECD, 2014 , p. 1). It resulted in an IMF-EU bail-out in Ireland with long-term economic, political and societal impact.

Under the terms of the bail-out, the Irish government had to adopt reform measures across all sectors to deliver change, stabilise and expand the economy. High-level leadership and coordination would deliver buy-in and oversight, along with 'whole-of-government' engagement, quarterly targets, all robustly monitored. A particular target was export-led economic growth in existing and emerging global markets. This national reform programme was entitled Action Plan for Jobs (APJ) and introduced in 2012 (appearing each year since then).

The goal of producing an FL education strategy appeared early on in the Government reforms, with the DES designated as lead agency. The specific context was: in order to grow new trade and export links and succeed in "winning abroad" (Department of Business, Enterprise and Innovation, 2014, p. 9), Ireland needed to look "outwards", and develop radical new capacities, so-called "Disruptive Reforms" (p. 3). Developing FL competence (incorporating intercultural awareness) across the public education system was identified as one such reform. The proposed FL strategy appeared for the first time in the 2014 Action Plan for Jobs, and confirmed highlevel government support for the decision. The statement read: "Develop and publish a languages education strategy including foreign languages" (p. 26). The measure had important outcomes, first a Call for submissions on a Foreign Languages in Education Strategy in August 2014 and then, the publication in December 2017 of Ireland's Strategy for Foreign Languages in Education 2017-2026, Languages Connect. 
It is important to note that the Framework for Consultation on a Foreign Languages in Education Strategy for Ireland launched in 2014 references the Language Education Policy Profile 2008 (Language Policy Division Strasbourg \& Department of Education and Skills, 2008) (henceforth Profile) in its opening paragraph as an informing influence shaping the work of the consultation and submission phase. Published in 2008, the Profile pre-dated the financial crisis and new 'whole-of-government' reforms in the public service, including in FL education. The Profile had resulted from an agreement reached between the DES and the Council of Europe Modern Languages Division to carry out a review of language education policy in Ireland at different levels. A key outcome of this process was the need for the Government to formulate a national language policy encompassing a broad range of sectors and drawing on international research and evidence of good practice.

Thus, in 2008, Ireland had a strong basis for a plan to develop a broad integrated language policy. This was overtaken by events due to the economic crisis, which hit that very same year. Many broader education policy measures were put on hold, but not the teaching of foreign languages. This led to the DES public call for submissions on foreign languages happening at a time when the 'winning abroad' policy was seen as vital to economic survival and recovery.

\section{Theoretical framework}

One of the defining features of deliberative democratic theories is the ideal of political justification (Cohen, 1997), which is synthesised in the principles of equal participation and free reasoning. Public engagement and the outcomes of its deliberations provide a major source of public justification. When applied to policy processes, deliberative theories emphasise that legitimacy and authorisation arise from the discussions and decisions made by a variety of relevant actors, including stakeholders and members of a society in conjunction with expert advice. A legitimate decision-making policy should thus be tied to participatory governance mechanisms that are open to multiple sources of public influence and to a reasonable incorporation of visions of value and common good (Dryzek, 2010). It is against this theoretical background that we examine the public consultation process launched by the Irish DES to develop and publish a strategy for foreign languages in education.

Given the emphasis on the value of languages for fulfilling Irish economic needs (Schroedler, 2018), also emerging from previous language education policies (e.g. Language Policy Division Strasbourg \& Department of Education and Skills, 2005-2007), our analysis draws on 
conceptual developments in the field of language economics (Grin, 2002; Chiswick \& Miller, 2007). More concretely, we focus on human capital theory, where human capital is seen as the "intrinsic productive capabilities of human beings", including earnings and broader measures of output (Eide \& Showalter, 2010, p. 27). As language competence can give rise to better socio-economic outcomes in regards to employability, professional mobility, competitiveness, and growth (European Commission, 2012), the application of human capital to language is straightforward: language learning is an investment in human capital at the expense of time and resources that may alter the value of the supply of an individual's labour in the market place in return. In short, language skills satisfy the requirements to be considered as human capital: they are productive, acquired at a cost, and embodied in the person (Chiswick \& Miller, 2007).

The acquisition and development of language skills are thus regarded as an important form of the individual's human capital as they make the individual more productive in the labour market (Chiswick \& Miller, 1995, p. 248). By human capital we consider both the individual dimension of the linguistic capital, which is the embodied linguistic repertoire that results from each person's choice, and the social dimension, or social capital, indicating those collective conditions in society that determine the formation of preferences on linguistic options (Wickström et al., 2018). The linguistic capital is then a matter of an individual investment on language-related goods that, to a large extent, are supplied by public authorities through the implementation of language policies in education. From this perspective, a language education policy aims at increasing aggregate economic welfare by providing private and social returns on language teaching (Grin, 2003).

The conceptualisation of language as capital lays stress on its economic value; however, other functions and values are also attached to language and language policies normally acknowledge, though to different degrees, the importance of language for purposes such as global citizenship, integration, social cohesion, and equality of opportunities. In other words, language policies are generally justified on grounds of economic efficiency as well as fairness of access and distribution of resources.

For this reason, Grin's (2002) conceptual distinction between market and non-market value of language provides us with an appropriate framework to identify and measure the distribution of the different types of social benefits emerging from the documents analysed in this study. 
- Market value of language: an asset potentially transferable into monetary profits in the labour market. Examples of this kind of value are economic productivity, marketoriented career opportunities, employability, job mobility, fulfilment of multinational requirements, and competition in the global job market.

- Non-market value of language: a market price is not directly assigned to language skills. It includes cultural awareness and openness, valuing of diversity, understanding of the language culture, access to other speaking communities, and individual benefits such as cognitive and affective development, transferable skills, learning additional languages, etc.

\section{Methodology}

Given the scope of the research, the corpus chosen for this study consists of the documents published by the DES before and after the consultation for Languages Connect as well as the submissions made by the public as a response to the consultation. Both quantitative and qualitative methods were used for the analysis. The following sections provide a detailed description of the corpus, of the two approaches to coding, and of the resulting data.

\subsection{The corpus}

The initial corpus comprised of: (i) the Framework for Consultation on a Foreign Languages in Education Strategy for Ireland (henceforth Framework) published in August 2014 by the Department of Education and Skills (DES), in line with their call for submissions to Ireland's Strategy for Foreign Languages; (ii) the submissions to the consultation (71 items); and (iii) Languages Connect, Ireland's Strategy for Foreign Languages in Education 2017-2026, the final document launched by the DES in December 2017.

The structure of the Framework is shown in Table 1. Part 1 of the document sets out the historical, social and cultural background that led to the Government's decision to draw up a strategy for FL in Ireland. In Part 2 a series of questions are asked, thus framing the public submissions. 
Framework for Consultation on a Foreign Languages in Education Strategy for Ireland (2014)

\section{Part 1 - Background}

National, educational, social, cultural, economic factors

Part 2 - Invitation to submit responses

Questions framing the consultation

1. Raising awareness: What measures should be undertaken to promote awareness, at national, community, enterprise and individual level, of the importance of language learning and to increase interest in and motivation for foreign language learning?

2. Supporting migrant languages in educational settings: How can we encourage our migrant children to become proficient in the language of their adopted community, while at the same time maintaining oral, written and cognitive academic language proficiency in their own mother tongue?

3. Learning and Teaching: How can foreign language learning be supported for students from post-primary educational settings and thereafter? You may wish to concentrate on one educational sector.

4. Teacher Education: How can we ensure an adequate and ongoing supply of highly-skilled, professional teachers/trainers of foreign language at all educational levels to meet ongoing and emerging needs?

5. Assessment and Qualifications: How can enhanced flexibility, choice and continuity in foreign language learning programmes, their assessment and accreditation be provided, particularly at Further and Higher Education?

6. Assuring Quality: What measures should be in place to support quality assurance measures, evaluation processes and research projects and to provide a knowledge and evidence base for policy making in the area of foreign languages?

7. Supporting Multilingualism in Business and Society: How can we promote a multilingual society and support service providers, both public and private, in meeting emerging needs? A. What role can the education system play? B. What role can employers play in enhancing the linguistic skills of their employees, particularly their Irish employees?

8. Other Comments: Please add any other comments you may have below that you believe are relevant to the development of the Strategy.

Table 1: Structure of the Framework

The public consultation was open from August 2014 to the end of October 2014. All 71 submissions are available on the DES website ${ }^{2}$ and have been divided by the DES into six categories: Cultural Institutes (3), Enterprise (3), Primary (6), Post-Primary (25), Third Level (16), and Other Organisations and Individuals (18).

As part of the consultation process, two fora were held by the DES in 2015. As stated on the DES website, the forum held in February, provided an opportunity to a number of those who had made submissions to present and discuss their view. The second forum was held in June, with a focus on FL teaching and learning in the universities. Due to a lack of detailed information available about the two fora, their results are not included in our analysis. 
After an initial reading of the documents, it was decided to scope the introductory programmatic part of the Framework, Part 1, as it provides the social, political, and economic context to 'develop and publish' Languages Connect and lays down its foundational principles.

A review of the submissions showed that 10 had been made by state bodies, agencies, and associations with links to government structures. It was thus decided to subdivide the submissions corpus into two separate sub-corpora. Sub-corpus 1 (Submissions Non-Gov) included submissions from stakeholders in the Education Sector, from Cultural Institutes, Enterprise, and individuals (61). Sub-corpus 2 (Submissions Gov) contained submissions from state bodies and state agencies linked to the government. This latter group was made up of 10 submissions respectively from the Department of Jobs, Enterprise and Innovation (DJEI), the Expert Group on Future Skills Needs (EGFSN), the Teacher Education Section of the DES, SOLAS $^{3}$, the Teaching Council, the Post-Primary Languages Initiative (PPLI), the National Agency for Erasmus+ (Leargas), and three offices of the Education and Training Boards Ireland (ETBI).

\subsection{Quantitative approach. Step one}

After organising the initial corpus into four corpora, the first stage of the coding commenced. All documents (Framework, two sub-corpora of submissions, and Languages Connect) were converted into Microsoft Word files and uploaded on SketchEngine ${ }^{4}$, an online free tool for the analysis of language corpora. Only 67 documents out of the original 71 submissions could be uploaded on SketchEngine, as 4 documents could not be converted into Microsoft Word files (two handwritten submissions and one scanned photo of a document in the Other Documents and Individuals category, plus one scanned photo of a document in the Third Level category). The SketchEngine search was designed to produce a set of quantitative data through a lexical search for a list of value-based lemmas indicating a market or a non-market value of language, listed in Table 2.

Lemmas indicating market value: employ*; econom*; business*; trade*; export*; compan*; recruit*; sale*; work (N); workplace*; work placement*; market* $(\mathrm{N})$; marketplace; client*; supplier*.

Lemmas indicating non-market value: integrat*; inclusiv*; cultur*; multicult*; cohes* social inclusion; identit*; citizen*

Table 2: List of value-based lemmas

The search on SketchEngine provided evidence of the occurrence and frequency per million (fxm) of each lemma in each of the four corpora, as shown in Table 3 and Table 4. 


\begin{tabular}{|c|c|c|c|c|}
\hline Lemma & $\begin{array}{l}\text { Framework } \\
4,918 \text { words }\end{array}$ & $\begin{array}{c}\text { Languages Connect } \\
14,156 \text { words }\end{array}$ & $\begin{array}{c}\text { Submissions No Gov } \\
112,747 \text { words }\end{array}$ & $\begin{array}{c}\text { Submissions Gov } \\
\mathbf{2 4 , 7 5 8} \text { words }\end{array}$ \\
\hline employ* & 22 fxm 3799 & 56 fxm 3402.81 & $\begin{array}{l}232 \mathrm{fxm} \\
1818.35\end{array}$ & 48 fxm 1717.84 \\
\hline econom* & 8 fxm 1381.45 & $23 \mathrm{fxm} 1397.58$ & $90 \mathrm{fxm} 705.4$ & 19 fxm 679.98 \\
\hline business & 7 fxm 1208.77 & $12 \mathrm{fxm} 729.17$ & $181 \mathrm{fxm} 1418.63$ & 48 fxm 1717.84 \\
\hline trade & 10 fxm 1726.82 & $11 \mathrm{fxm} 668.41$ & 43 fxm 337.02 & 8: fxm 286.31 \\
\hline export* & 0 & $5 \mathrm{fxm} 303.82$ & 32 fxm 250.81 & $21 \mathrm{fxm} 751.56$ \\
\hline compan* & $3 \mathrm{fxm} 518.5$ & 9 fxm 546.88 & 75 fxm 587.83 & $25 \mathrm{fxm} 894.71$ \\
\hline recruit* & $4 \mathrm{fxm} 690.73$ & $1 \mathrm{fxm} 60.76$ & $21 \mathrm{fxm} 164.59$ & $6 \mathrm{fxm} 214.73$ \\
\hline sale* & 0 & $2 \mathrm{fxm} 121.53$ & $10 \mathrm{fxm} 78.38$ & $22 \mathrm{fxm} 787.32$ \\
\hline work* $(\mathbf{N})$ & $3 \mathrm{fxm} 518.5$ & 13 fxm 789.94 & $152 \mathrm{fxm} 1191.33$ & 25 fxm 894.71 \\
\hline workplace & 0 & $1 \mathrm{fxm} 60.76$ & 19 fxm 148.92 & $2 \mathrm{fxm} 71.58$ \\
\hline work placement* & 0 & $4 \mathrm{fxm} 243.06$ & $14 \mathrm{fxm} 109.73$ & $7 \mathrm{fxm} 250.52$ \\
\hline market* $(\mathbf{N})$ & $5 \mathrm{fxm} 863.41$ & $10 \mathrm{fxm} 607.64$ & $49 \mathrm{fxm} 384.05$ & $21 \mathrm{fxm} 751.56$ \\
\hline marketplace* & 0 & $1 \mathrm{fxm} 60.76$ & $1 \mathrm{fxm} 7.84$ & $1 \mathrm{fxm} 35.79$ \\
\hline client* & 0 & $1 \mathrm{fxm} 60.76$ & $5 \mathrm{fxm} 39.19$ & $2 \mathrm{fxm} 71.58$ \\
\hline supplier* & 0 & $1 \mathrm{fxm} 60.76$ & $3 \mathrm{fxm} 23.51$ & $1 \mathrm{fxm} 35.79$ \\
\hline
\end{tabular}

Table 3: Market-value lemmas in the corpora. Frequency per million.

\begin{tabular}{|l|l|l|l|l|}
\hline \multicolumn{1}{|c|}{ Lemma } & $\begin{array}{c}\text { Framework } \\
\mathbf{4 , 9 1 8} \text { words }\end{array}$ & $\begin{array}{c}\text { Languages Connect } \\
\mathbf{1 4 , 1 5 6} \text { words }\end{array}$ & $\begin{array}{c}\text { Submissions No Gov } \\
\mathbf{1 1 2 , 7 4 7} \text { words }\end{array}$ & $\begin{array}{l}\text { Submissions Gov } \\
\mathbf{2 4 , 7 5 8} \text { words }\end{array}$ \\
\hline integrat* & 0 & $1 \mathrm{fxm} 60.76$ & $106 \mathrm{fxm} 830.8$ & $17 \mathrm{fxm} 608.4$ \\
& & & & \\
\hline
\end{tabular}




\begin{tabular}{|c|c|c|c|c|}
\hline inclusiv* & 0 & 1 fxm 60.76 & 10 fxm 78.38 & 5 fxm 178.94 \\
\hline cultur* & $18 \mathrm{fmx} 3108.27$ & 38 fxm 2309.05 & 274 fxm 2147.54 & 44 fxm 1574.69 \\
\hline multicult* & $1 \mathrm{fxm} 172.68$ & 6 fxm 364.59 & 13 fxm 101.89 & 2 fxm 71.58 \\
\hline cohes* & $1 \mathrm{fxm} 172.68$ & $1 \mathrm{fxm} \quad 60.76$ & 10 fxm 78.38 & 7 fxm 250.52 \\
\hline social inclusion & 0 & 2 fxm 121.53 & 0 & 0 \\
\hline identit* & 2 fxm 345.36 & $1 \mathrm{fxm} \quad 60.76$ & 12 fxm 94.05 & 2 fxm 71.58 \\
\hline citizen* & 8 fxm 1381.45 & 15 fxm 911.47 & 38 fxm 297.83 & 1 fxm 35.79 \\
\hline
\end{tabular}

Table 4: Occurrence and frequency of non-market-value lemmas in the corpora.

\subsection{Quantitative approach. Step two}

In addition to the dual classification of the value of language outlined above, we introduced a second set of value variables into this part of the analysis. This was done to take into account the approach taken by Languages Connect towards the Irish linguistic environment. With this aim, a distinction between (i) language competence and (ii) language diversity was made. The former refers to the general term 'knowing languages' that is, the value assigned to any additional language competence on top of English, Irish or any other first language(s). The latter pertains specifically to the value attributed to the coexisting languages of immigrant origin at societal level. These languages are known by terms such as home, community, ethnic, or heritage languages. As Languages Connect uses the term 'heritage' throughout, this study will refer to these languages accordingly, in line with the DES document. Overall, four subcategories result from the combination of our target variables, as shown in Table 5: 


\begin{tabular}{|l|l|l|}
\hline & MARKET & NON-MARKET \\
\hline $\begin{array}{l}\text { (A) LANGUAGE } \\
\text { COMPETENCE }\end{array}$ & $\begin{array}{l}\text { (1A) Market value of language } \\
\text { competence }\end{array}$ & $\begin{array}{l}\text { (2A) Non-market value of language } \\
\text { competence }\end{array}$ \\
\hline $\begin{array}{l}\text { (B) LINGUISTIC } \\
\text { DIVERSITY }\end{array}$ & $\begin{array}{l}\text { (1B) Market value of linguistic } \\
\text { diversity }\end{array}$ & $\begin{array}{l}\text { (2B) Non-market value of linguistic } \\
\text { diversity }\end{array}$ \\
\hline
\end{tabular}

Table 5: Value assessments of language

This framework enables us to situate our study within the construct of "language as commodity" (Heller, 2003), which has become well-known in applied and sociolinguistics. More specifically, we acknowledge recent critiques of viewing language skills as human capital (Holborow, 2018). First, by including the non-market-value of language, we recognise the complex and multifaceted nature of language learning and go beyond the reductionist view that language skills are concerned only with economic investment and returns. Moreover, this focus enables us to spotlight some contributors' critical stances towards the policy orientation that were not incorporated into the final outcome and may have gone unnoticed by the general public. Secondly, by particularising the analytical focus on the languages of immigrant origin within the country's linguistic landscape, we consider the hierarchy of values towards different types of languages (Piller, 2016) that is implicit in instrumental approaches to language as an economic resource.

In line with text analytical approaches to judgements about values and beliefs in discourse (Schneider et al., 2007), our analysis relies on value statements, a basic unit of ascribing value to a specific object in discourse (see Soler \& Erdocia, forthcoming). For this part of the quantitative analysis, the documents were coded manually, which allowed all but one of the submissions to be coded. It was decided to disregard one anonymous submission in the group Other submissions and individuals. The 70 items were read through and scanned for sequences of meaning expressing value statements or units ascribing market and non-market-value to language competence and language diversity. We considered each value statement found in a contribution in terms of the four subcategories to which it related, and coded it accordingly (see Table 5). Statements that did not fit neatly into one subcategory were excluded from the analysis.

\subsection{Qualitative approach}


After the quantitative analysis of the data, we moved on to the qualitative analysis to address our second research goal, namely to compare the submissions that resonate with government discourse with those problematising the market-led value of languages and pointing to the potential pitfalls of this discourse. For this purpose, firstly, we drew on the value statements resulting from the second step of the quantitative analysis $(n=70)$ and used an interpretative approach to analyse the discourse in the Framework, in Languages Connect, as well as in those submissions which are in line with them. Secondly, we identified and analysed complementary and alternative stances towards the marketplace ideology embedded in the government discourse. Simply put, we considered those counter discourses in the submissions that contest any aspect of the predominant economic approach to language in the policy documents.

For this part of the analysis, we relied on directed content analysis (Hsieh \& Shannon, 2005), an interpretative approach that provides predictions about the variables of interest and suggestions for the key concepts in the new investigation. This approach also helps to determine relationships between codes. Drawing on both prior research in the Irish and the international context, (King \& Carson, 2016; Holborow, 2018; Little \& Kirwan, 2019) and on the insight from the quantitative analysis, we used a preliminary coding scheme to locate the discursive stances at play in the value statements: principles guiding foreign language policy; hierarchy of languages; integration of minority language pupils; structural social inequalities; diversity and inclusive education. This was followed by multiple in-depth readings of the corpus to identify and organise tendencies and patterns emerging from the consultation. After the revision, connection and extension of the initial coding, the data was reorganised and three final categories defined: (1) limits of the market approach, (2) "new Irish" as resource, (3) critical approach to language.

\section{Data analysis: quantitative approach}

The sets of quantitative and qualitative data resulting from the coding of the corpora were at first analysed separately. The analysis of the quantitative data gave an initial impression of the framing of the documents. The following sections provide an account of the two steps of the quantitative analysis. The analysis of the market-value and non-market-value lemmas identified in the documents will be presented first. This will be followed by the analysis of language-value statements pertaining to the market or non-market value of language competence and linguistic diversity. 


\subsection{Step 1. Analysis of the quantitative data: market-value lemmas}

The data shown in Table 3 were analysed comparing their fxm in the four corpora, as represented in Figure 1.

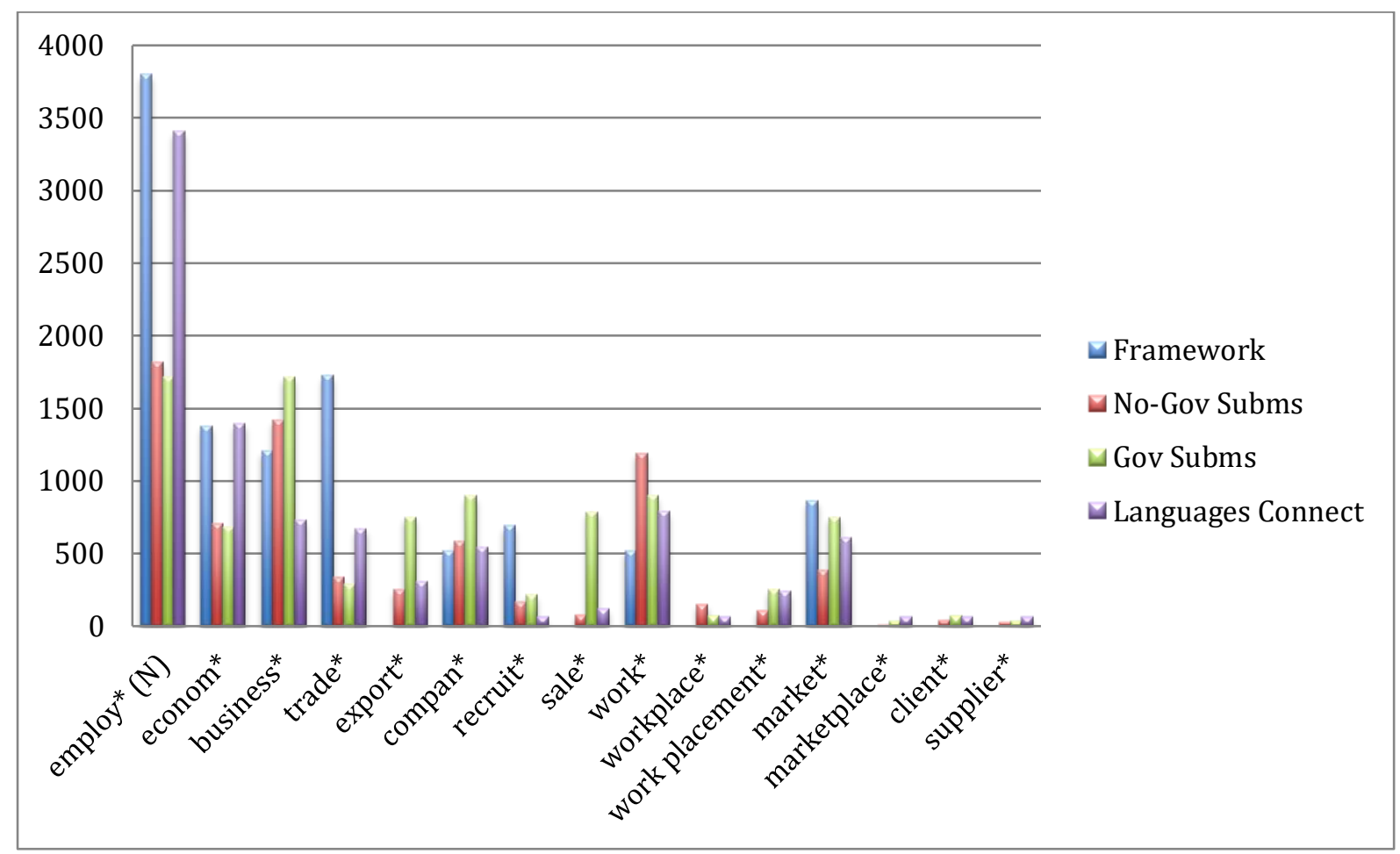

Figure 1: Frequency of market-value lemmas in the corpora.

The data in the chart above are presented following a chronological approach, showing the corpora from left to right, according to their year of publication/production. It is clear in Table 3, as well as in Figure 1, that most of the market-value lemmas (11) had a higher frequency of use in the documents published by the DES (i.e. Framework and Languages Connect) than in the submissions to the consultation process. These lemmas are; employ*, work placement*, market ${ }^{*}$, marketplace ${ }^{*}$, client $^{*}$, supplier $^{*}$, recruit $^{*}$, export $^{*}$, econom $^{*}$, trade $^{*}$, and sale ${ }^{*}$.

At times, the difference in frequency between the corpora is striking, as is the case with the lemma employ*, whose frequency both in the Framework $(\mathrm{fmx}=3799)$ and in Languages Connect $(\mathrm{fmx}=3402.81)$ is roughly twice the frequency in the Non-Gov ( $\mathrm{fxm}=1818.35)$ and Gov (fxm=1717.84) submissions. Similarly, we note that the lemma econom* and trade $^{*}$ also appear about twice as many times in the Framework and Languages Connect compared to the submissions, with econom* having a frequency of $\mathrm{fxm}=1381.45$ in the Framework and a frequency of fxm=1397.58 in Languages Connect, as opposed to fxm=705.4 in the Non-Gov submissions and $\mathrm{fxm}=679.98$ in the Gov submissions. As regards the lemma trade*, we notice 
a fxm=1726.82 in the Framework and a fxm=668.41 in Languages Connect, whereas the NonGov submissions record fxm=337.02 and the Gov submissions show fxm=286.31.

Interestingly, and probably to be expected, some market-value words (6) present a higher occurrence in the Gov submissions than in the Non-Gov submissions. This can be noticed for the lemmas sale ${ }^{*}$, export $^{*}$, work placement* ${ }^{*}$, market $^{*}$, client $^{*}$, and compan*. Three of these five lemmas, work placement*, market ${ }^{*}$, and client $^{*}$, are used in the Gov submissions with a frequency similar to the one noted in the Framework (when the lemma occurs) and in Languages Connect, as shown in Table 6.

\begin{tabular}{|lllll|}
\hline Lemma & Framework & $\begin{array}{l}\text { Non-governmental } \\
\text { submissions }\end{array}$ & $\begin{array}{l}\text { Governmental } \\
\text { submissions }\end{array}$ & $\begin{array}{l}\text { Languages } \\
\text { Connect }\end{array}$ \\
\hline $\begin{array}{l}\text { work } \\
\text { placement* }\end{array}$ & 0 & Fxm 109.73 & Fxm 250.52 & Fxm 243.06 \\
\hline market* $(\mathbf{N})$ & Fxm 863.41 & Fxm 348.05 & Fxm 751.56 & Fxm 607.64 \\
\hline client* & 0 & Fxm 39.19 & Fxm 60.76 & Fxm 71.58 \\
\hline export* & 0 & Fxm 250.81 & Fxm 751.56 & Fxm 303.82 \\
\hline sale* & 0 & Fxm 78.38 & Fxm 787.32 & Fxm 121.53 \\
\hline compan* & Fxm 518.5 & Fxm 587.83 & Fxm 894.71 & Fxm 546.88 \\
\hline
\end{tabular}

Table 6: Market-value lemmas with higher frequency in governmental submissions

Again, in the case of $\operatorname{market}^{*}(\mathrm{~N})^{5}$ we note a remarkable difference between its frequency in the Framework, in the Gov submissions and in Languages Connect, compared to the Non-Gov submissions.

Finally, three lemmas: work $^{*}(\mathrm{~N})$, workplace $^{*}$, and business* , appear to show a different trend, presented in Table 7. 


\begin{tabular}{|lllll|}
\hline Lemma & Framework & $\begin{array}{l}\text { Non-governmental } \\
\text { submissions }\end{array}$ & $\begin{array}{l}\text { Governmental } \\
\text { submissions }\end{array}$ & $\begin{array}{l}\text { Languages } \\
\text { Connect }\end{array}$ \\
\hline work* $(\mathbf{N})$ & Fxm 518.5 & Fxm 1191.33 & Fxm 894.71 & Fxm 789.94 \\
\hline workplace* & 0 & Fxm 148.92 & Fxm 71.58 & Fxm 60.74 \\
\hline business* & $\begin{array}{l}\text { Fxm } \\
1208.77\end{array}$ & Fxm 1418.63 & Fxm 1717.84 & Fxm 729.17 \\
\hline
\end{tabular}

Table 7: Market-value lemmas with higher frequency in non-governmental submissions

As the table above shows, the three lemmas have a much higher frequency in the Non-Gov submissions than in Languages Connect and the first two lemmas have a higher frequency than in the Gov submissions.

The analysis of the market-value lemmas in the corpora shows that the documents produced by the DES, namely the Framework and Languages Connect, make a more extensive use of words indicating a market-value than the contributions submitted by the public. The much higher frequency of the lemma employ* in the Framework and in Languages Connect appears to highlight a strong correlation between languages and employability. Also, the high frequency of the lemmas trade* and econom* in the same documents contributes to framing the focus on language skills as necessary for national economic development. It is interesting to note that the governmental focus resonates with the contributions from state bodies, state agencies and associations close to the Government.

\subsection{Step 1. Analysis of the quantitative data: non-market value lemmas}

The data shown in Table 4 were analysed comparing their fxm in the four corpora, as represented in Figure 2. 


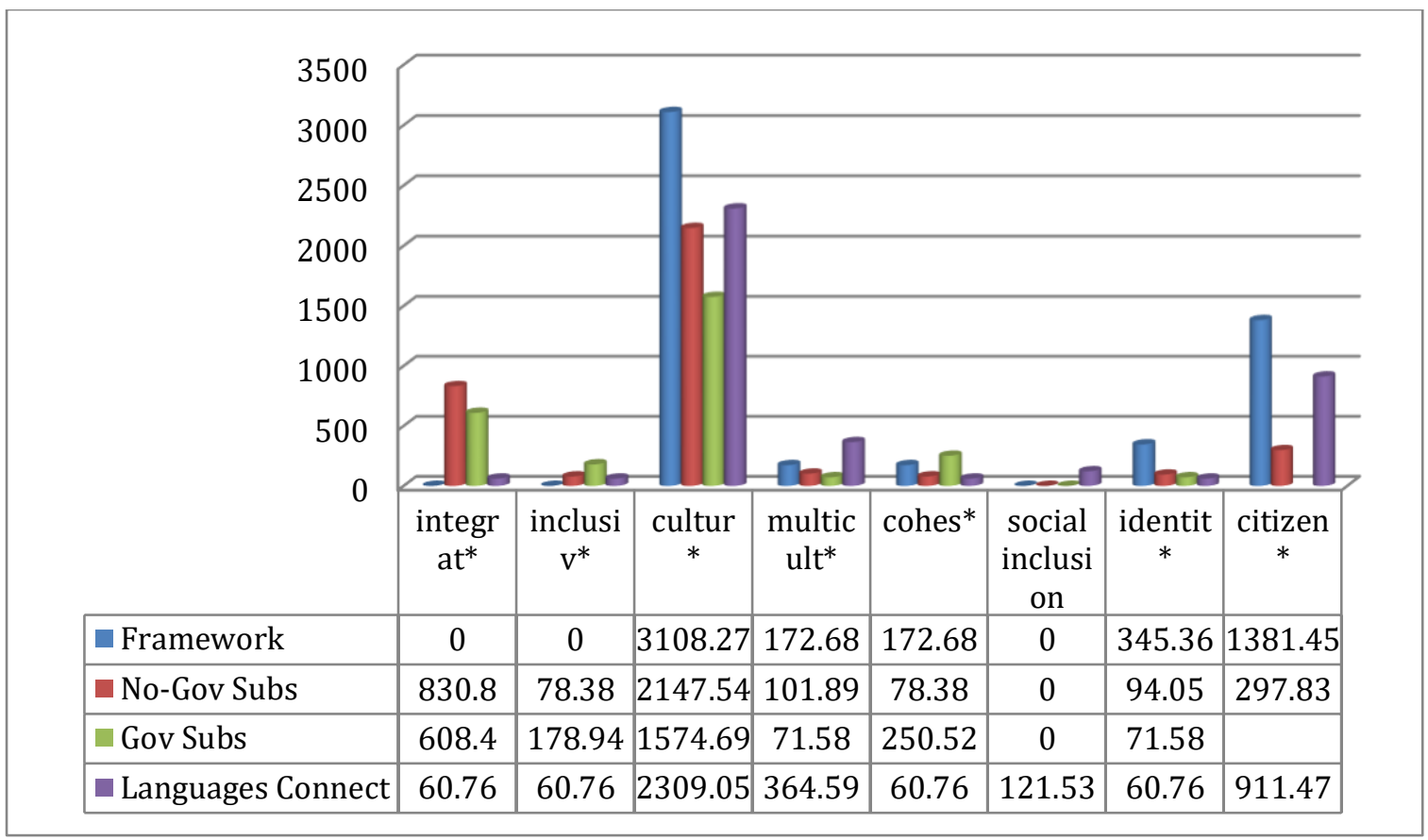

Figure 2: Frequency of non-market-value lemmas in the corpora

It is worth noting that the data above paint a scenario that does not follow the expectations created by the analysis of the market-value terms in section 5.1. In fact, five of the eight nonmarket-value lemmas (cultur*, multicultur*, cohes*, identit*, citizen*) present a higher frequency in at least one of the documents published by the DES, either the Framework or Languages Connect. The case of words formed with the lemma cultur* is quite striking, as the data appears with a very high frequency in all four corpora, with almost double the difference between the frequency in the Framework and in the 10 Gov submissions. It can be assumed however that words such as culture, cultural, etc. would be quite frequent in this type of documents, whether they are policy documents or more discursive submissions from the public.

Only two lemmas: integrat* and inclusiv*, occur more frequently in the submissions. This does not support an assumption whereby the submissions (particularly the Non-Gov ones) would use more non-market-value lemmas. At this point it can be interesting to note that the average frequency of non-market-value lemmas is lower than the frequency of market-value lemmas in all corpora analysed, as shown in Figure 3. 


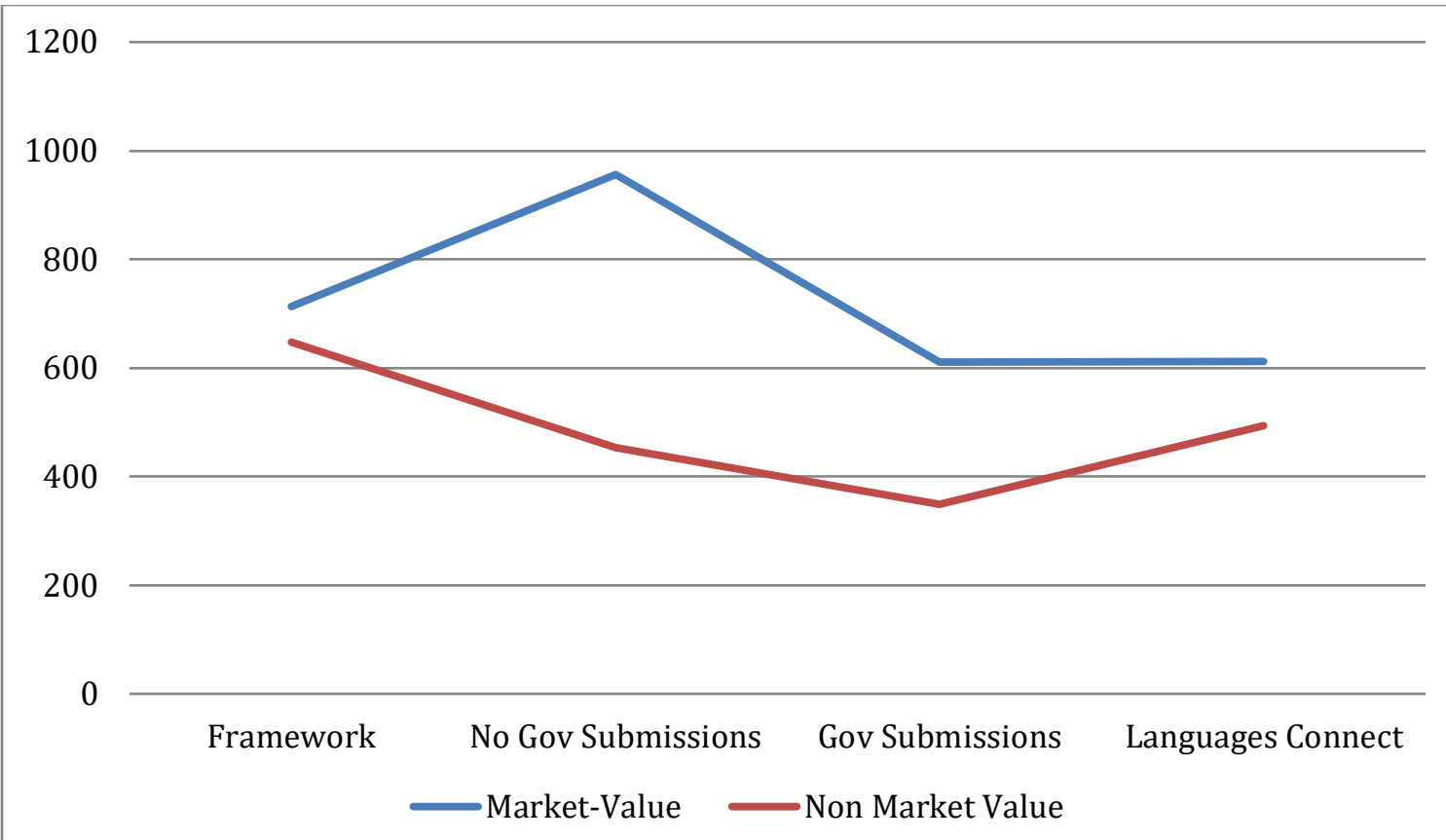

Figure 3: Average frequency per million of market-value and non-market-value lemmas in the corpora

\subsection{Step 2. Analysis of the quantitative data: language value statements}

The aim of this second part of the quantitative analysis is to compare the participants' submissions to the goals section in Languages Connect (pp. 20-38). This is key to determining whether and how the submissions are in line with the final policy document. The results presented are based on the language value statements coded in the corpora, according to the four subcategories listed in Section 4.3. Table 8 provides an overview of the occurrence of the value statements in the corpora.

\begin{tabular}{lllll}
\hline & Statements & Per & Submissions & LC \\
\hline & Market value & 3.4 & $\begin{array}{l}\text { Documents including } \\
\text { code }\end{array}$ & $\begin{array}{l}\text { Goals } \\
\text { section }\end{array}$ \\
$\begin{array}{l}\text { Language } \\
\text { competence }\end{array}$ & $\begin{array}{l}\text { Non-market } \\
\text { value }\end{array}$ & 1 & $32 / 70$ & 22 \\
Larket value & 0.6 & $13 / 70$ & 10 \\
Linguistic diversity & $\begin{array}{l}\text { Non-market } \\
\text { value }\end{array}$ & 0.7 & $32 / 70$ & 2 \\
\hline
\end{tabular}

Table 8: Frequency of value statements: submissions and Languages Connect

Results in this second part of the quantitative analysis confirm those of the first part; first, market-value statements are more frequent than non-market value statements. Secondly, 
Languages Connect uses more extensively both market-value and non-market value statements than the contributions submitted by the public. However, no significant differences between government and non-government bodies are found this time.

On the other hand, this step in the analysis shows new insight into the data; the frequency of value statements referred to language competence ('knowing languages') is much more common than the frequency of statements about linguistic diversity (languages of immigrant origin). This indicates that language competence was the main focus of discussion, whilst linguistic diversity did not receive as much attention. It is clear that, within the category of language competence, market value statements - including the number of submissions in which they appear - are significantly higher than non-market ones. This does not apply to the category of linguistic diversity. In addition, the most striking difference between value statements in Languages Connect and in the submissions lies within the category of language competence and includes both market value and non-market value statements.

It is also important to note that whereas Languages Connect contains 22 market value statements in the category of language competence - the highest occurrence for all subcategories - the frequency of the occurrence of market value statements per submission is only 3.4. This indicates that the market value approach in Languages Connect is overemphasised by comparison with the submissions.

The following section presents the major findings on the discursive mechanisms used by participants in their submissions to the DES consultation, and compares them with the policy documents.

\section{Data analysis: qualitative approach}

This section presents the analysis of the qualitative data resulting from the coding of the corpora, which led to the following categories: limits of the market approach; the "new Irish" as resource; critical approach to language. These are presented below.

\subsection{Limits of the market approach}

While the potential economic advantages of language learning are by no means in doubt, a warning about a too excessive economic-oriented approach to language policy emerges from the analysis of the submissions. Contributors often underline the importance of non-market 
positive values such as social, (inter)cultural, and cognitive benefits of plurilingualism and their impact at the societal level. Many argue for a balanced approach to valuing the importance of languages. One stakeholder explains that otherwise,

"framing the rationale for a languages policy exclusively in terms of economic imperatives will not best serve an increasingly diverse and mobile Irish society into the future" (ASTI)

A general trend in those who question a focus on language as an instrumental asset is to highlight the importance of the individual dimension of learning. Sometimes contributors explicitly suggest complementary approaches to the meaning of language learning for individuals in a global context. This could be an expected contribution, given that most participants are language instructors, language-related professionals and probably speakers of additional languages. Participants often draw connections between the social and individual benefits of languages, when referring to non-market values. It is the case, for instance, of lessmentioned factors such as the affective dimension of learning languages:

"This is about celebrating diversity and the individual, (regardless of how he/she selfidentifies), their community and their sense of belonging in society and encouraging them of the necessity, desirability and achievability of speaking, listening, reading and writing in other languages. A pro-business message might neglect some of these educational and socio-emotive benefits" (Kevin Hickey-EIL)

Interestingly, diversity is often invoked in many of these implicit and explicit critiques of the approach taken by the consultation even though the Framework itself incorporates diversity as "a social, cultural and national resource" (p. 3) to be nurtured. Diversity is argued to be the basis for a different approach to valuing language, one that is not in line with instrumental accounts. This position seemingly attributes an intrinsic value to linguistic diversity, which thus becomes a sort of morally valued constituent on its own. The intrinsic value has been claimed as a reason for the preservation and protection of a particular language or culture (Musschenga, 1998) although most liberal theorists of multiculturalism do not share this position. 
In any case, highlighting the limits of a utilitarian approach to language policy occasionally implies a criticism of the consultation process. From this perspective, the consultation document can be seen as biased towards the economic value of language or not appropriately balanced, such as in the following comment:

"Though the introductory section of the Framework (Why a foreign languages strategy) acknowledges the benefits of a multilingual society for economic, social and individual well-being, this balanced assessment regrettably disappears in favour of the economic arguments as the document progresses. In this way, the document undermines its own starting point" (Kristin Brogan - One Voice for Languages)

This type of comment shows the critical engagement of some participants and stakeholders in the public consultation process led by a government body. It also illustrates the active advocacy role of some contributors for alternative models to the discourse of profit in language education (Heller \& Duchêne, 2012).

\section{2. "New Irish" as resource}

One of the main themes underlying the debate is the needs of the Irish work market in a global economy and, more specifically, how language policy measures in education can improve the efficiency of the Irish economy. Many contributions with an economic focus provide good instances of the notions of interdiscursivity and intertextuality, or of the way certain ideas or values circulate and are reproduced among various public discourses and texts in multiple settings (Blommaert, 2005).

One such idea is that Ireland is a small country with an open economy that is necessarily dependent on the global market. This economic statement is frequently used in the sphere of politics as a basis for policy decisions in other areas, such as education. As language policy in education is often organically tied to broader areas of public policy, it is perhaps unsurprising that such an economic statement would be included in different discursive events. For example, it is evoked in the foreword to Languages Connect by the former Minister for Educations and Skills, Mr Richard Bruton TD: "The education system must support learners of all ages to (...) develop the skills to function and thrive in our modern global economy" (p. 5). The same idea is expressed in the Framework and in other parts of Languages Connect (Executive Summary) as well as in many contributions. 
One of the consequences of being a modern global economy is that Ireland is now home to immigrants from all over the world. Diversity is thus part of the country's linguistic environment. Indeed, many contributions introduce multilingualism as a public good with potential positive externalities, a point which is illustrated in the next extract:

"Education and Training Boards Ireland has argued that migrants coming from nonEnglish speaking homes can become one of our greatest assets. If we assist them to acquire competence in their heritage languages, we will be going a significant way to meeting our need for workers fluent in both English and a foreign language" (IBEC)

This excerpt expresses the view that speakers of migrant languages can help reverse the shortage of competent speakers of foreign languages for specific business purposes in the country (see Schroedler, 2018). However, this is not simply a comment on the linguistic needs of the workforce. Instead, what emerges in some statements is the assumption that the education system cannot (and perhaps will not) supply a sufficient number of local speakers of languages of trade:

\footnotetext{
"Businesses hire language competent staff from abroad, we should not overlook the potential of using community/home speakers of other languages for business purposes at home and abroad. It is unlikely that our school system will produce many competent Mandarin speakers, for example, from our local Irish population. But first or second heritage speakers of Mandarin and other languages could perform these roles as required" (Eugene McKendry-NICILT Belfast)
}

This position seems to have a number of questionable premises: first, it establishes a clear-cut distinction between foreign and heritage language abilities of learners. Secondly, it seems to simplify the complex process of heritage language acquisition and development. However, the most relevant point here is that it raises doubts about the very aim of Languages Connect. Even if we assume that second generation heritage speakers can reach a proficiency level for business, the question that follows is does foreign language teaching and learning exist at the core of Languages Connect's goals to fulfil the requirements of the domestic job market? Put differently, and following the previous example: are heritage speakers of Chinese a priority for Languages Connect? To what extent does it target local (mainly English/Irish L1) learners of Chinese simply to meet the market demand? 
An unduly utilitarian approach to language policy often results in the explicit valuing of only a small number of 'prestige languages'. As shown in the quantitative analysis, there are constantly recurring references to languages of trade and business in the consultation and this may give the impression of the exclusion of other languages. The differing perspectives about linguistic diversity can be seen by comparing the next two excerpts:

"If English is essential, other languages may offer new trade opportunities (especially emerging markets such as Brazil, Russia, India, China but also the francophone countries with a huge potential market in Africa), and give a company a competitive edge" (Alliance Française)

"a market oriented approach (...) will only prioritise big, hegemonic languages and will leave a remarkable number of lesser-used languages — small-state, regional or minority languages" (Kristin Brogan - One Voice for Languages)

Following the idea of the second comment, privileging some languages over others could contribute to strengthening the hierarchically structured relation between languages (Piller, 2016). Therefore, a market value of linguistic diversity could set differentiated levels of valorisation and even celebration of multilingualism.

A careful balance on the way the value of language is reflected appears to exist in some parts of Languages Connect and the Framework (especially in the second part of Goal 2 "Cultivate the languages of new Irish"). In fact, many value statements throughout the Government documents include the market/non-market dichotomy in their wording, such as in this example:

"Ireland will be a nation which recognises the value that linguistic and cultural diversity delivers to individuals, society and the economy" (Languages Connect, p. 7)

However, the language-as-currency approach adopted in the whole process leads to a possible doubt as regards the real importance assigned to and the level of commitment towards other languages spoken in the country. Including both foreign and heritage languages as part of a single national strategy, and even within one goal (Goal 2), is an attempt to promote awareness of the importance of languages in general. However, since the strategy is aimed at foreign languages, thus excluding the two national languages, English and Irish, as noted by many 
submissions, one may reasonably wonder what kind of linguistic diversity is to be celebrated, why and what for.

\subsection{Critical approach to language}

The stance questioning the limits of the market-oriented approach to linguistic diversity includes some comments that can be classified as a critical approach to language (Tollefson, 2006). This approach refers to the problematisation of relations of power together with social change through language policy, and includes issues such as economic inequality, social injustice, cultural domination, and imparity of political participation (Piller, 2016). As in most governmental language policy documents, this critical stance is largely absent in Languages Connect. In the consultation, a small number of participants connect language with notions such as equality, justice and power. This critical position is nicely captured in the following extract:

"Language policy cannot be seen in isolation from a type of intercultural education which is rooted in the principles of critical multiculturalism, in that issues of equality and justice are paramount. In this context, a focus on language cannot be separated from a study of societal power relations. It, therefore, cannot become a debate purely about linguistics or merely about 'strategies'. In order to genuinely support migrant languages in educational settings, educators and policymakers must engage in a broader political discussion which recognises the power differentials within society and in schools" (Barbara O’Toole - Ed MIE)

This participant not only depicts language as a complex phenomenon, a characterisation that can be found in many of the explanations by language professionals, but she problematises an alleged neutral or technocratic approach to language policy. As research on LPP has demonstrated since its inception, debates on language policy are hardly ever only about language. Making policy choices inevitably requires an ideological positioning and course of action. Similarly, framing the consultation on language policy in Irish education is not free of ideological considerations. The comment above points to the relationship between power and educational institutions; more precisely, it suggests that society's structures are also locally produced and, consequently, both policy-making and implementation need a context-sensitive approach in order to adhere the micro to the macro dimension (Van Dijk, 2009). 
The relationship between power and language is also addressed from a methodological perspective. The following extract offers a critical approach to language teaching, one that promotes transformation and endeavours to foster the agentive capacity of minority speakers:

"By understanding the interaction between critical thinking, social interaction, learner identity, power and language acquisition, teachers can reflect on their classes and see if they are reproducing or transforming the social world of the language minority student, giving them the tools necessary to make the transition from an oppressed to an empowered member of society" (Jennifer Bruen, Niamh Kelly, Dorothy Kenny - DCU)

It is noteworthy that relatively few participants engaged with such a critical viewpoint to language. This is perhaps even more striking considering that most contributors are language educators, practitioners and even researchers. A possible reason for this general positioning in the discussion is that it was tightly framed by the consultation's questions (see Table 1). This could explain how the conceptualisation of the value of language in Languages Connect does not differ significantly from the framework that was proposed as starting point for the policy process.

\section{Discussion and concluding remarks}

As detailed above, it is within the particular circumstances of a post-crisis Ireland that the Languages Connect initiative was planned and launched. Measures to restore economic stability, such as export-oriented business growth, created new demands for the job market. Nowadays, there exists a significant mismatch of supply and demand of language skills that might lead to competitiveness disadvantages (Schroedler, 2018). Consequently, political responses were needed for the new market's linguistic requirements. Be it a form of lobbying for publicly funded language training for workers or a window of opportunity for a wide range of language stakeholders, language as an economic resource is the driving force behind the policy. As shown in our analysis, the idea of the Irish market situated within a global economy is one of the main themes underlying the policy-making process. This in turn is based on the assumption that language policy measures in education can improve employability and the efficiency of the Irish economy. These ideas are present not only in the policy documents and the governmental discourses but are fully or partially assumed by many submissions, which adopt a market-value stance when advocating for language skills and language learning. Therefore, as in the case of other educational settings (Källkvist \& Hult, 2016), a preliminary 
conclusion may be drawn, namely that intertextuality and interdiscursivity have been basic mechanisms in the formation of FL policy in Ireland in more recent times.

Although this is an evidence-based assertion, such an interpretation falls short when it comes to a full reading of the policy-making process as it does not take into account that some privileged actors dominate the shaping of policy ideas. One should not forget that this was a Government-led initiative; in other words, the participatory nature of the consultation procedure was not free of power relations. Indeed, submissions depicting critical perspectives about language as well as those proposing alternative models for language education are scarce, as noted in the qualitative analysis. Also, it is noticeable that a good number of the submissions were penned by governmental bodies or agencies close to the government. Further, the language adopted in the submissions often reflected the governmental discourse. We can speculate that the reason for this is that the consultation document was tightly framed in the way questions were formulated. This point can be elaborated further with an example, as we find a clear correlation between (a) some of the consultation Framework's questions guiding the contributions on the one hand, and, on the other hand (b) the resulting goals, and (c) certain ideological assumptions in Languages Connect:

(a) 7. Supporting Multilingualism in Business and Society --- How can we promote a multilingual society and support service providers, both public and private, in meeting emerging needs? (Consultation Framework, p. 16. Emphasis added);

(b) GOAL 4: Enhance employer engagement in the development and use of trade languages (Languages Connect, p. 36);

(c) The Strategy (...) also acknowledges that the education sector cannot succeed without the assistance of other sectors. This is especially relevant to the enterprise sector (Languages Connect, p. 40).

By responding to question 7 (a), contributors need to uncritically assume that their role as language educators also includes the provision of language competent staff for service providers. Because of the way this question was framed, the resulting goal 4 (b) can be at least partially deemed as a conditioned and anticipated outcome. If this argument is correct, we can conclude that some participants did not properly address the economic approach to language taken by authorities and most probably could not do otherwise. 
Having said that, introducing the concept of power relations into the enquiry of how and why certain ideas and values are not only reproduced but also privileged among discourses within public participatory processes could shed some new light on the way power relations behind the argumentation are manifested. This, we believe, deserves further scrutiny.

As shown in both parts of the quantitative analysis, the Framework and Languages Connect contain a high frequency of market-value lemmas and market-value statements compared with the contributions submitted by the public. Another important finding is that linguistic diversity did not receive as much attention as language competence. In this respect, it is worth noting the limited presence in all parts of our corpus of important societal (and non-market) principles with clear connection to community languages, such as social cohesion and inclusion. This is notwithstanding that both Languages Connect and the Framework include some references to such principles. We found that the Framework's intention to recognise and support heritage languages mutates into the promotion of heritage language speakers as an economic resource and into the subsequent promotion of certain languages over others. On the one hand, research on the relation between language and returns to human capital among migrants has almost exclusively focused on the proficiency of the dominant language in the host society (Adserà \& Pytliková, 2016). Therefore, connecting heritage language command with better economic opportunities constitutes a novel approach to language policy in education that may alleviate some of the disadvantages and discrimination faced by linguistically diverse population (Piller, 2016). On the other hand, this may raise some questions about the real distributive impact of this language policy on heritage speakers of small or medium-sized languages (Grin, 2003). And this perspective also casts doubts on the extent to which this capital of heritage distinction approach (Blackledge \& Creese, 2012) represents another case of commodification of language and identity brought about by globalised economy (Heller, 2003). In any case, it is not clear to us what kind of diversity is to be celebrated, why and what for. In relation to the Framework document, this also could indicate a potential discontinuity between Part 2 (series of questions formulated for the public consultation) and Part 1, focused on the social and cultural background for the language strategy. This was noted by some participants, as outlined above. Here, we are not questioning the validity of an involvement of the private sector. As a matter of fact, this sector is presumably going to reap an important part of the benefits of the investment costs of the implementation of Languages Connect through access to a more multilingual work-force. Hence, it seems both logical and reasonable to expect a stronger partnership between education stakeholders and other sectors (for a similar strategy, see British 
Academy et al., 2020). This includes a more committed engagement by the business community, given that for sustainable economic development to occur in Ireland an investment in language and intercultural skills is vital (Schroedler, 2018). Instead, bearing in mind that participatory and deliberative procedures are meant to provide legitimacy for policy decisions, what is at stake here is the extent to which ideological positionings such as "the education sector cannot succeed without the assistance of other sectors. This is especially relevant to the enterprise sector" can be claimed to be solely based on findings of "an extensive consultation process" (Languages Connect, p. 40).

To conclude, even though the consultation process was a bold and well-intentioned move towards the incorporation of language-related professionals and stakeholders into policymaking, one cannot but wonder if the procedural mechanisms used for the participation may have prevented a more transparent, evidence-supported, and even critical deliberation about what kind of approach to language policy in education (including national languages and compulsory foreign language education at primary level) Ireland needs.

\section{References}

Adserà, A., \& Pytliková, M. (2016). Language and migration. In V. Ginsburg, \& S. Weber (Eds.), The Palgrave handbook of economics and language (pp. 342-365). Palgrave Macmillan.

Blackledge, A., \& Creese, A. (2012). Pride, profit and distinction: Negotiations across time and space in community language education. In A. Duchêne, \& M. Heller (Eds.), Language in late capitalism: Pride and profit (pp. 116-141). Routledge.

Blommaert, J. (2005). Discourse: A critical introduction. Cambridge University Press.

British Academy, Arts and Humanities Research Council, Association of School and College Leaders, British Council, and Universities UK (2020). Towards a national languages strategy: Education and skills. Retrieved July 21, 2020, from https://www.thebritishacademy.ac.uk/publications/towards-national-languages-strategyeducation-and-skills/

Bruen, J. (2013). Towards a national policy for languages in education: The case of Ireland. European Journal of Language Policy, 5(1), 99-114. https://doi.org/10.3828/ejlp.2013.5 Bruen, J. (2019). Languages Connect and the languages of the new Irish. Teanga, 26, 116-123. https://doi.org/10.35903/teanga.v26i0.134 
Chiswick, B., \& Miller, P. (1995). The endogeneity between language and earnings: International analyses. Journal of labor economics, 13(2), 246-288.

Chiswick, B., \& Miller, P. (2007). The economics of language. Routledge.

Cohen J. (1996). Procedure and substance in deliberative democracy. In S. Benhabib (Ed.), Democracy and difference: Contesting the boundaries of the political (pp. 95-119). Princeton University Press.

Department of Business Enterprise and Innovation (2014). Action plan for jobs. Retrieved March 5, 2020, from https://dbei.gov.ie/en/Publications/Action-Plan-for-Jobs-2014.html Department of Education and Skills (2014). Framework for consultation on a foreign languages in education strategy for Ireland. Retrieved January 2, 2020, from https://www.education.ie/en/Schools-Colleges/Information/Curriculum-andSyllabus/Foreign-Languages-Strategy/Foreign-Languages-Strategy.html

Department of Education and Skills (2017). Languages connect, Ireland's strategy for foreign languages in education 2017-2026, 2017. Retrieved November 15, 2019, from https://www.education.ie/en/Schools-Colleges/Information/Curriculum-andSyllabus/Foreign-Languages-Strategy/Foreign-Languages-Strategy.html

Dryzek, J. (2010). Foundations and frontiers of deliberative governance. Oxford University Press.

Eide, E., \& Showalter, M. (2010). Human capital. In D. Brewer, \& P. McEwan (Eds.). International encyclopedia of education, economics of education section (pp. 342-346). Elsevier.

European Commission (2012). Language competences for employability, mobility and growth. In European Commission, communication from the commission rethinking education: Investing in skills for better socio-economic outcomes. Retrieved February 2, 2020, from https://eur-

lex.europa.eu/LexUriServ/LexUriServ.do? uri=SWD:2012:0372:FIN:EN:PDF

Grin, F. (2002). Using language economics and education economics in language education policy. Council of Europe. Retrieved March 8, 2020, from https://www.ecml.at/Portals/1/documents/CoE-documents/GrinEN.pdf

Grin, F. (2003). Language planning and economics. Current issues in language planning, 4(1), 1-66. https://doi.org/10.1080/14664200308668048

Heller, M. (2003). Globalization, the new economy, and the commodification of language and identity. Journal of Sociolinguistics, 7(4), 473-492. https://doi.org/10.1111/j.14679841.2003.00238.x 
Heller, M., \& Duchêne, A. (2012). Pride and profit: Changing discourses of language, capital and nation-state. In A. Duchêne, \& M. Heller, M. (Eds.), Language in late capitalism: Pride and profit (pp. 1-21). Routledge.

Holborow, M. (2018). Language skills as human capital? Challenging the neoliberal frame. Language and Intercultural Communication, 18(5), 520-532. https://doi.org/10.1080/14708477.2018.1501846

Hsieh, H. F., \& Shannon, S. E. (2005). Three approaches to qualitative content analysis. Qualitative health research, 15(9), 1277-1288.

Källkvist, M., \& Hult, F. M. (2016). Discursive mechanisms and human agency in language policy formation: Negotiating bilingualism and parallel language use at a Swedish university. International Journal of Bilingual Education and Bilingualism, 19(1), 1-17. https://doi.org/10.1080/13670050.2014.956044

King, L., \& Carson, L. (Eds.). (2016). The multilingual city: Vitality, conflict and change. Multilingual Matters.

Language Policy Division Strasbourg, \& Department of Education and Skills (2008). Language education policy profile: Ireland 2005-2007. Retrieved January 13, 2020, from https://www.education.ie/en/Publications/Education-Reports/Council-of-EuropeLanguage-Education-Policy-Profile.pdf

Little, D., \& Kirwan, D. (2019). Engaging with linguistic diversity: A study of educational inclusion in an Irish primary school. Bloomsbury Publishing.

Lo Bianco, J. (2013). Role of deliberation in language policy and planning. In C. Chapelle (Ed.). The encyclopedia of applied linguistics (pp. 5004-5008). Blackwell.

Maguire, P. (Ed.). (2019). Foreign language learning and Ireland's Languages Connect strategy. Education and society, occasional papers, No. 1. http://nui.ie/publications/docs/2019/NUI-Foreign-Language-Learning.pdf

Musschenga, A. (1998). Intrinsic value as a reason for the preservation of minority cultures. Ethical Theory \& Moral Practice, 1(2), 201-225.

OECD (2014). Ireland's action plan for jobs: a preliminary review. Retrieved March 5, 2020, from http://www.oecd.org/ireland/Ireland-action-plan-for-jobs-review.pdf

Piller, I. (2016). Linguistic diversity and social justice: An introduction to applied sociolinguistics. Oxford University Press.

Ramberg, B. (2016). Shaping language: What deliberative legitimacy requires. Sociolinguistica, 30(1), 65-82. https://doi.org/10.1515/soci-2016-0005 
Royal Irish Academy, National Committee for Language, Literary and Cultural Studies (2011). National languages strategy. Retrieved March 6, 2020, from https://www.ria.ie/sites/default/files/national_languages_strategy_august_2011.pdf

Schneider, S., Nullmeier, F., \& Hurrelmann, A. (2007). Exploring the communicative dimension of legitimacy: Text analytical approaches. In A. Hurrelmann, S. Schneider, \& J. Steffek (Eds.). Legitimacy in an age of global politics (pp. 126-55). Palgrave Macmillan.

Schroedler, T. (2018). The value of foreign language learning: A study on linguistic capital and the economic value of language skills. Springer.

Soler, J., \& Erdocia, I. (forthcoming). Language policy and the status of languages in contemporary Catalonia: A public debate. European Journal of Language Policy.

Tollefson, J. (2006). Critical theory in language policy. In T. Ricento (Ed.). An introduction to language policy: Theory and method. Blackwell Publishing.

Van Dijk, T. (2009). Critical discourse studies: A sociocognitive approach. In R. Wodak, \& M. Meyer (Eds.). Methods of critical discourse analysis (pp. 62-86). Sage.

Wickström B., Templin T., \& Gazzola M. (2018). An economics approach to language policy and linguistic justice. In M. Gazzola, T. Templin, B. Wickström (Eds.). Language policy and linguistic justice (pp. 3-64). Springer.

\footnotetext{
${ }^{1}$ While there are some theoretical differences between policy and strategy, we use the term policy to refer to Languages Connect, as it is a more common designation in language policy and planning research.

${ }^{2}$ https://www.education.ie/en/Schools-Colleges/Information/Curriculum-and-Syllabus/Foreign-Languages-

Strategy/Foreign-Languages-Strategy.html

${ }^{3}$ Irish state agency with responsibility for assisting those seeking employment

${ }^{4}$ https://www.sketchengine.eu/

${ }^{5}(\mathrm{~N})$ indicates that the results include only nouns.
} 